\title{
ArcheoSciences
}

Revue d'archéométrie

33 (suppl.) | 2009

Mémoire du sol, espace des hommes

\section{Confrontation of geophysical survey, soil studies and excavation data to evidence tillage erosion}

\section{Armelle Querrien, Joël Moulin and Alain Tabbagh}

\section{(2) OpenEdition}

1 Journals

\section{Electronic version}

URL: https://journals.openedition.org/archeosciences/1576

DOI: 10.4000/archeosciences. 1576

ISBN: 978-2-7535-1599-4

ISSN: 2104-3728

Publisher

Presses universitaires de Rennes

\section{Printed version}

Date of publication: 30 October 2009

Number of pages: 195-198

ISBN: 978-2-7535-0943-6

ISSN: $1960-1360$

\section{Electronic reference}

Armelle Querrien, Joël Moulin and Alain Tabbagh, "Confrontation of geophysical survey, soil studies and excavation data to evidence tillage erosion", ArcheoSciences [Online], 33 (suppl.) | 2009, Online since 30 October 2011, connection on 21 September 2021. URL: http://journals.openedition.org/ archeosciences/1576; DOI: https://doi.org/10.4000/archeosciences.1576 


\title{
Confrontation of geophysical survey, soil studies and excavation data to evidence tillage erosion
}

\author{
Armelle Querrien*, Joël Moulin ** and Alain TABbagh ${ }^{* * *}$
}

Key words: geophysical survey, soil studies, archaeological features, tillage erosion.

Three different surveys have been performed at Monbaron in the Champagne Berrichonne region to the south of Levroux (Indre, France). The first survey (1992), using the square array resistivity method, aimed to identify the presence of buried archaeological features, mainly ditches. The second one (1996), corresponding to a test of a new multidepth instrument, aimed both to assess its abilities and to increase the extent of the surveyed area. The preservation of buried features, observed by comparing successive results, determined the extent of later excavations. Lastly, a magnetic survey and pedological study carried out recently helped to identify the role of natural and anthropogenic processes in the disintegration of archaeological features. The confrontation of different data also helped in assessing the 3D modelling interpretation of resistivity data. The combined results are a demonstration of « agricultural » erosion.

\section{SURVEY DATA}

Oblique air photos taken at Montbaron during the 1976 summer drought show a site with large ditches. This site was considered as unthreatened because of the absence of deep ploughing in this area. However, it remains under surveillance due to its presumed importance for medieval archaeology. A resistivity survey using the "Rateau " continuous pulled technique with a $1 \mathrm{~m}$-sided square array covered 2 ha in 1992 (measurement G. Ducommet) (Fig. 1). The initial interpretation of these data suggested the existence of two superimposed sites.

A second experiment was undertaken in 1996 (measurement M. Dabas, C. Panissod) using the MUCEP system with three different depths of investigation in the "Vol de canards "

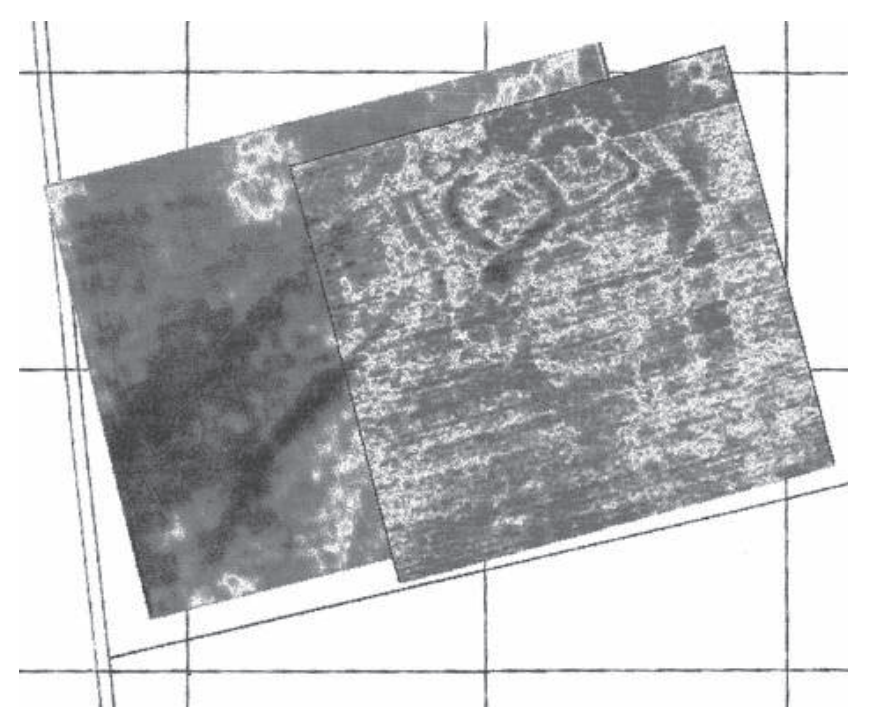

Figure 1 (see color plate): Results of the 1992 one-meter square array apparent resistivity survey superimposed on those of the 1996 resistivity survey.

* CNRS, UMR 8589, LAMOP, (armelle.querrien@free.fr).

** Chambre d'agriculture de l'Indre, (J.Moulin@indre.chambagri.fr).

*** Chambagri.fr UPMC/CNRS, UMR 7619, Sisyphe, (alain.tabbagh@upmc.fr). 
configuration. The survey covered 3 ha with a large overlap of the 1992 survey (Fig. 1). The multi-depth investigation established some of the ditches as being quite deep, but most of the archaeological features, such as pits or buildings, appeared to be at a shallow depth; limestone outcrops and a karst collapse were observed (and later confirmed by excavation).

The site was interpreted as a fortified house. A hundred meters to the north, a square enclosure (dating from the first century AD) suggested that medieval features could touch and partly cut these older ones.

However, compared to the first one, the results of the second survey showed a significantly reduced magnitude of the anomalies corresponding to the different features, in keeping with their presumed shallow depth (less than $0.5 \mathrm{~m}$ ). The most likely explanation for this was a reduction of their volume by agricultural work, the impact of which has been neglected before. An excavation campaign was thus arranged, the authorities having recognized the geophysical survey results as proof of an emergency.

Magnetic prospecting (measurement C. Panissod, 2000) was performed before the end of the excavation campaign in order to complete the resistivity results and to identify the possible presence of heated features (Fig. 2).

\section{ExCAVATIONS}

Based on the apparent resistivity maps and taking into consideration the extent of the area under study, a powershovel was chosen for carrying out the excavation. This was because the cutting off was very strong and no stratigraphic relationship could be established between the different featu-

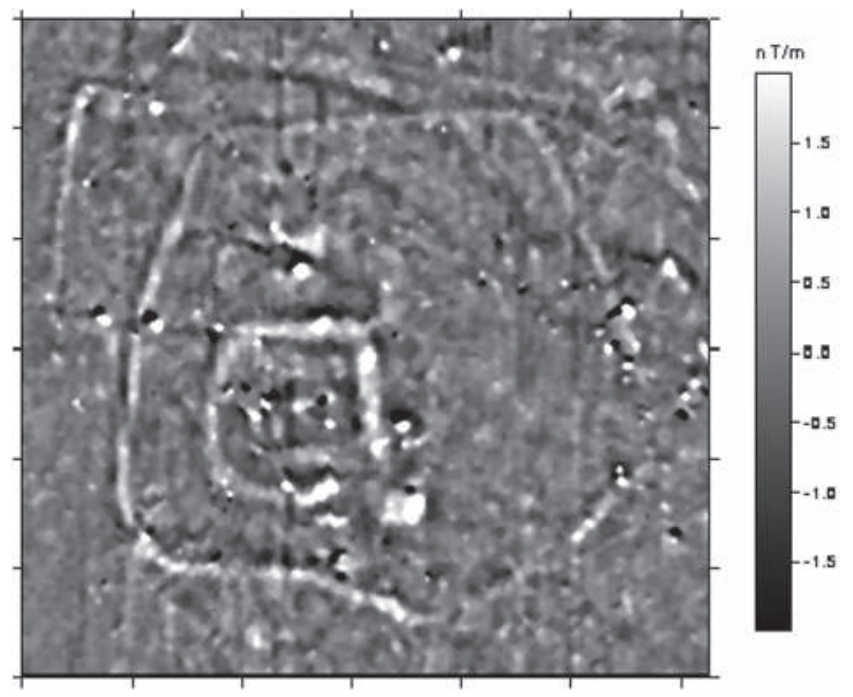

Figure 2: Magnetic survey results, gradiometric measurements res, the bottom of which could only be recognised. To map all the features appearing just below the cultivated layer and to separate anthropogenic from natural ones, $1100 \mathrm{~m}^{2}$ were stripped, and nine different areas corresponding to a total of $3200 \mathrm{~m}^{2}$ were excavated. Twenty vertical sections reaching the calcareous basement were studied over the anomalies located next to the medieval enclosure for a total length of $560 \mathrm{~m}$ (Fig. 3). In all the excavations, the power-shovel was guided by the survey maps.

\section{CONFRONTATION BETWEEN RESISTIVITY DATA AND EXCAVATIONS}

Resistivity data was confronted with excavation results on four Iron Age features, ten undated features and ten medieval features comprising ditches and built remains. A karst collapse was also studied. Several questions were considered, including which kind of feature is recognisable on the survey map and by what sort of anomalies? What are the differences between the 1992 and 1996 resistivity results and does 3D modelling of resistivity data correspond to archaeological and/or pedological observations?

\section{NATURAL EROSION VERSUS ANTHROPOGENIC LEVELLING}

Due to its position on top of the plateau at $172 \mathrm{~m}$ a.s.l., a significant risk of wind erosion is to be expected, but both soil granularity and the carbonate context would normally limit this erosion. In the absence of human activity the soil would be considered as of low sensitivity. The slope is less than $2 \%$, but the thinness of topsoil facilitates ploughing abrasion. Two sections observed during a former (1976) excavation and again during the 1998-2000 campaign show that the $0.25 \mathrm{~m}$ and $0.45 \mathrm{~m}$ thickness had vanished from the stratigraphy under arable soil between those two dates.

By comparison with a morphologically similar site (Les Coudrières $1.7 \mathrm{~km}$ to the north), it is possible that about $1 \mathrm{~m}$ of deposits under arable soil have disappeared at Montbaron since the end of the medieval settlement. Modern agricultural equipment, like powerful tractors, should be considered as mainly responsible for this rapid erosion. This the farmers do not accept, even given archaeological evidence.

Three different approaches were applied at Montbaron to highlight the importance of the problem caused by agricultural practices. A confrontation of results exemplifies how the excavation drew on survey results and how 3D modelling can be assessed. Soil science allowed natural phenomena 


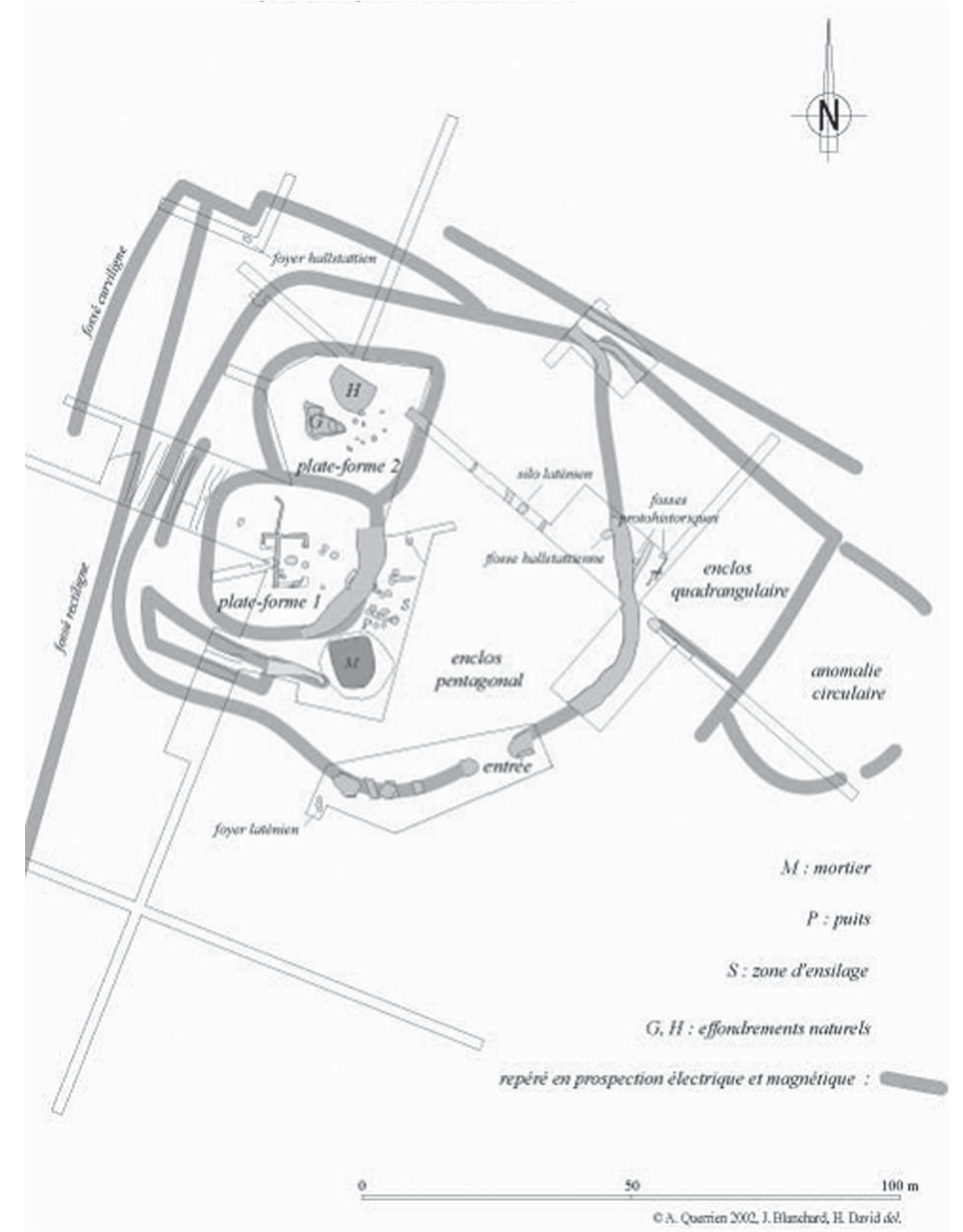

Figure 3: Archaeological features revealed by surveying and observed in excavations

to be distinguished from anthropogenic ones and it also identified the physical characteristics of soils responsible for resistivity and magnetic field variations. Information about the filling of features (materials and granularity) is also essential for exact interpretation.

\section{References}

Buchsenschutz, O., 1980. Sondages sur la pièce de la Fosse à Montbaron (Levroux, Indre), Revue archéologique du Centre, 73 à $76: 55-63$.

Dabas, M., 1998. La prospection géophysique. In Ferdière, A., (dir.). La prospection, Collection Archéologiques, Editions Errance, Paris, 161-206.

Panissod, C., 1997. Prospection électrique et électrostatique à faible profondeur à l'aide de systèmes multipôles permettant la description de structures en 3-D, Thèse de l'Université de Paris VI, Paris. 
QuerRIEN, A., (DIR.), 2004. La résidence aristocratique de Montaron (Levroux, Indre), fin XI ${ }^{\mathrm{e}}$-début XIII ${ }^{\mathrm{e}}$ siècle. Archéologie médiévale, 34: 65-174.

Takken, I., Govers, G., Jetten, V., Nachtergaele, J., Steegen, A., Poesen, J., 2001. Effects of tillage on runoff and erosion patterns. In Voorhees, W.B., Borresen, T., Colvin, T., Tullberg, J., Wilkins, D. (dir.). Soil \& Tillage, Elsevier Science B.V.
VANNiÈre, B., 2001. Feu, agro-pastoralisme et dynamiques environnementales en France durant l'Holocène. Analyses du signal incendie, approches sédimentologiques et études de cas en Berry, Pyrénées et Franche-Comté, thèse de l'Institut national agronomique Paris-Grignon. 